\title{
Front Matter: Volume 7992
}

, "Front Matter: Volume 7992," Proc. SPIE 7992, Optical Technologies for Telecommunications 2010, 799201 (21 April 2011); doi: 10.1117/12.895165

SPIE Event: Optical Technologies for Telecommunications 2010, 2010, Ufa, SPIE. Bashkortostan, Russian Federation 


\title{
PROCEEDINGS OF SPIE
}

\section{Optical Technologies for Telecommunications 2010}

\author{
Vladimir A. Andreev \\ Vladimir A. Burdin \\ Albert H. Sultanov \\ Oleg G. Morozov \\ Editors
}

17-18 November 2010

Ufa, Russian Federation

Organized by

Ufa State Aviation Technical University (Russian Federation)

Povolzhskiy State University of Telecommunications and Informatics (Russian Federation)

Kazan State Technical University (Russian Federation)

RBIT (Russian Federation)

Published by

SPIE 
The papers included in this volume were part of the technical conference cited on the cover and title page. Papers were selected and subject to review by the editors and conference program committee. Some conference presentations may not be available for publication. The papers published in these proceedings reflect the work and thoughts of the authors and are published herein as submitted. The publisher is not responsible for the validity of the information or for any outcomes resulting from reliance thereon.

Please use the following format to cite material from this book:

Author(s), "Title of Paper," in Optical Technologies for Telecommunications 2010, edited by Vladimir A. Andreev, Vladimir A. Burdin, Albert H. Sultanov, Oleg G. Morozov, Proceedings of SPIE Vol. 7992 (SPIE, Bellingham, WA, 2011) Article CID Number.

ISSN 0277-786X

ISBN 9780819485632

Published by

SPIE

P.O. Box 10, Bellingham, Washington 98227-0010 USA

Telephone +1 3606763290 (Pacific Time) · Fax +1 3606471445

SPIE.org

Copyright (C) 2011, Society of Photo-Optical Instrumentation Engineers

Copying of material in this book for internal or personal use, or for the internal or personal use of specific clients, beyond the fair use provisions granted by the U.S. Copyright Law is authorized by SPIE subject to payment of copying fees. The Transactional Reporting Service base fee for this volume is $\$ 18.00$ per article (or portion thereof), which should be paid directly to the Copyright Clearance Center (CCC), 222 Rosewood Drive, Danvers, MA 01923. Payment may also be made electronically through CCC Online at copyright.com. Other copying for republication, resale, advertising or promotion, or any form of systematic or multiple reproduction of any material in this book is prohibited except with permission in writing from the publisher. The CCC fee code is 0277-786X/11/ \$18.00.

Printed in the United States of America.

Publication of record for individual papers is online in the SPIE Digital Library.

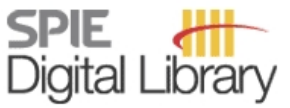

SPIEDigitalLibrary.org

Paper Numbering: Proceedings of SPIE follow an e-First publication model, with papers published first online and then in print and on CD-ROM. Papers are published as they are submitted and meet publication criteria. A unique, consistent, permanent citation identifier (CID) number is assigned to each article at the time of the first publication. Utilization of CIDs allows articles to be fully citable as soon they are published online, and connects the same identifier to all online, print, and electronic versions of the publication. SPIE uses a six-digit CID article numbering system in which:

- The first four digits correspond to the SPIE volume number.

- The last two digits indicate publication order within the volume using a Base 36 numbering system employing both numerals and letters. These two-number sets start with 00, 01, 02, 03, 04, $05,06,07,08,09,0 A, 0 B \ldots 0 Z$, followed by 10-1Z, 20-2Z, etc.

The CID number appears on each page of the manuscript. The complete citation is used on the first page, and an abbreviated version on subsequent pages. Numbers in the index correspond to the last two digits of the six-digit CID number. 


\section{Contents}

vii Conference Committee

ix Introduction

\section{SESSION 1}

799202 Dual port MZM based optical comb generator for all-optical microwave photonic devices [7992-01]

D. L. Aybatov, O. G. Morozov, T. S. Sadeev, Kazan State Technical Univ. (Russian Federation)

799203 PMD compensation using Faraday rotation and LiNbO3-based DGD emulator [7992-02]

A. Z. Tlyavlin, M. R. Musakaev, Ufa State Aviation Technical Univ. (Russian Federation)

799204 Unconventional signal detection techniques with Gaussian probability mixtures adaptation in non-AWGN channels: full resolution receiver [7992-03]

S. M. Chabdarov, A. F. Nadeev, D. E. Chickrin, R. R. Faizullin, Kazan State Technical Univ. (Russian Federation)

799205 New approach of fiber optic telecommunication lines upgrade by dense dispersion managed solitons (Invited Paper) [7992-04]

V. A. Burdin, K. A. Volkov, Povolzhskiy State Univ. of Telecommunications and Informatics (Russian Federation)

\section{SESSION 2}

799206 Investigation of defects of refractive index profile of silica graded-index multimode fibers [7992-05]

A. V. Bourdine, D. E. Praporshchikov, K. A. Yablochkin, Povolzhskiy State Univ. of Telecommunications and Informatics (Russian Federation)

799207 Mode excitation by laser source in multimode optical fiber under special single-mode optical fiber use [7992-06]

V. A. Burdin, A. V. Bourdine, K. A. Yablochkin, Povolzhskiy State Univ. of Telecommunications and Informatics (Russian Federation)

799208 Design of multimode optical fibers with low differential mode delay [7992-07]

A. V. Bourdine, Povolzhskiy State Univ. of Telecommunications and Informatics (Russian Federation)

799209 Optical switching element based on selective dielectric mirrors and fractal heterostructure [7992-08]

V. Kh. Bagmanov, S. V. Kostrov, A. Kh. Sultanov, Ufa State Aviation Technical Univ. (Russian Federation) 
7992 OA Microstructured multimode optical fiber for differential mode delay compensation [7992-09] A. V. Bourdine, V. A. Burdin, Povolzhskiy State Univ. of Telecommunications and Informatics (Russian Federation); O. R. Delmukhametov, Ufa State Aviation Technical Univ. (Russian Federation)

7992 OB Creation of the new optical switch model [7992-10] A. I. Salikhov, Ufa State Aviation Technical Univ. (Russian Federation); L. L. Doskolovich, Image Processing Systems Institute (Russian Federation)

7992 OC All-optical microwave photonic filter based on two-frequency optical source [7992-11] O. G. Morozov, T. S. Sadeev, Kazan State Technical Univ. (Russian Federation)

\section{SESSION 3}

7992 OD Optical refractometric FBG biosensors: problems of development and decision courses [7992-12]

O. A. Stepustchenko, Ministry of Internal Affairs, Tatarstan Republic (Russian Federation); O. G. Morozov, Ministry of Internal Affairs, Tatarstan Republic (Russian Federation) and Kazan State Technical Univ. (Russian Federation); I. R. Sadykov, G. A. Morozov, P. E. Denisenko, Kazan State Technical Univ. (Russian Federation); A. N. Gorshunova, Povolzhskiy State Univ. of Telecommunications and Informatics (Russian Federation)

7992 OE Structural minimization of fiber optic sensor nets for monitoring of dangerous materials storage [7992-13]

O. G. Morozov, Kazan State Technical Univ. (Russian Federation); G. A. Morozov, Kazan State Technical Univ. (Russian Federation) and Povolzhskiy State Univ. of Telecommunications and Informatics (Russian Federation); V. V. Kourevin, Kazan State Technical Univ. (Russian Federation); V. G. Kouprianov, Ministry of Defence Dept. (Russian Federation); E. P. Denisenko, Kazan State Technical Univ. (Russian Federation); S. G. Alyushina, Povolzhskiy State Univ. of Telecommunications and Informatics (Russian Federation)

\section{SESSION 4}

7992 OF Strategy choice for fiber optic transmission lines maintenance [7992-14] V. A. Andreev, A. A. Voronkov, Povolzhskiy State Univ. of Telecommunications and Informatics (Russian Federation); L. N. Shafigullin, JSC Tattelecom (Russian Federation)

7992 OG Chromatic dispersion and PMD measurements of optical fiber [7992-15] S. B. Yanyshev, I. H. Galeev, JSC Bashinformsvyaz (Russian Federation); I. L. Vinogradova, A. N. Garifinov, A. I. Salikhov, A. H. Sultanov, Ufa State Aviation Technical Univ. (Russian Federation)

$7992 \mathrm{OH} \quad$ Localization method of fiber optics defects on short length of optical cable [7992-16] E. V. Dmitriev, Povolzhskiy State Univ. of Telecommunications and Informatics (Russian Federation)

7992 Ol Results of field inspection of fiber optical communication line using polarization optical time domain reflectometer [7992-17]

M. V. Dashkov, Povolzhskiy State Univ. of Telecommunications and Informatics (Russian Federation) 
7992 0J Researches of incrementation of attenuation in optical fiber at deformation of optical cable loose tubes [7992-18]

T. G. Nikulina, I. N. Alekhin, S. A. Gavryushin, Povolzhskiy State Univ. of Telecommunications and Informatics (Russian Federation)

7992 OK Researches of optical cable stability in the microduct to effect of freezing water [7992-19] V. A. Burdin, T. G. Nikulina, I. N. Alekhin, S. A. Gavryushin, Povolzhskiy State Univ. of Telecommunications and Informatics (Russian Federation)

\section{SESSION 5}

$7992 \mathrm{OL} \quad$ Training course on optical telecommunication and multimedia technologies for specialists in endoscopic video surgery [7992-20]

A. F. Agliullin, MedFarmServis (Russian Federation); V. F. Gusev, JSC ICL (Russian Federation); O. G. Morozov, R. R. Samigullin, A. Iv. Akul'shin, N. V. Bagapov, Kazan State Technical Univ. (Russian Federation)

Author Index 
Downloaded From: https://www.spiedigitallibrary.org/conference-proceedings-of-spie on 25 Apr 2023

Terms of Use: https://www.spiedigitallibrary.org/terms-of-use 


\title{
Conference Committee
}

\author{
Conference Chairs \\ Vladimir A. Andreev, Povolzhskiy State University of \\ Telecommunications and Informatics (Russian Federation) \\ Vladimir A. Burdin, Povolzhskiy State University of Telecommunications \\ and Informatics (Russian Federation) \\ Albert H. Sultanov, Ufa State Aviation Technical University \\ (Russian Federation) \\ Oleg G. Morozov, Kazan State Technical University (Russian Federation)
}

Program Committee

V. Ch. Bagmanov, Ufa State Aviation Technical University (Russian Federation)

Christian Schaffer, Dresden Technical University (Germany)

E. N. Gordeev, UNI (Russian Federation)

O. V. Goryachkin, Povolzhskiy State University of Telecommunications and Informatics (Russian Federation)

V. G. Kartashevski, Povolzhskiy State University of Telecommunications and Informatics (Russian Federation)

G. A. Morozov, NIZ PRE Kazan State Technical University (Russian Federation)

A. F. Nadeev, Kazan State Technical University (Russian Federation)

A. I. Salikhov, Ufa State Aviation Technical University (Russian Federation)

Yu. M. Spodobaev, Povolzhskiy State University of Telecommunications and Informatics (Russian Federation)

A. Z. Tlyavlin, Ufa State Aviation Technical University (Russian Federation)

R. G. Usmanov, BashkirEnergo (Russian Federation)

I. L. Vinogradova, Ufa State Aviation Technical University

(Russian Federation)

Y. B. Zubarev, MNITI (Russian Federation) 
Downloaded From: https://www.spiedigitallibrary.org/conference-proceedings-of-spie on 25 Apr 2023

Terms of Use: https://www.spiedigitallibrary.org/terms-of-use 


\section{Introduction}

This volume contains a selection of papers presented at the tenth International Conference on Optical Technologies for Telecommunications. The conference was held 17-18 November 2010 at Ufa State Aviation Technical University, Ufa, Russia.

The conference covered a large range of problems in optical technologies in telecommunications. The papers accepted for publication in this volume were chosen from papers presented at the conference on the topics mentioned in the table of contents.

We have no doubt that the proceedings from this conference will be helpful for both scientists and specialists working in the fields of telecommunication technologies. 
Downloaded From: https://www.spiedigitallibrary.org/conference-proceedings-of-spie on 25 Apr 2023

Terms of Use: https://www.spiedigitallibrary.org/terms-of-use 